\title{
Asset tangibility, information asymmetries and intangibles as determinants of family firms leverage
}

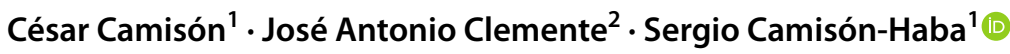

Received: 29 May 2021 / Accepted: 1 January 2022 / Published online: 19 January 2022

(C) The Author(s), under exclusive licence to Springer-Verlag GmbH Germany, part of Springer Nature 2022

\begin{abstract}
Using a sample of Spanish tourism small and medium-sized firms, we have tested the impact of family control, publicly-available information and tangibility on financial structure, providing a multi-theoretical model that incorporates contributions from the classical theory of finance, inspired by agency theory, the behavioural theory of the firm and strategic theory. The results point to the need to jointly consider the effects of information transmission practices, asset investment decisions and ownership structures on debt capacity. The results show how family control is associated with propensity to take on debt, so that the desire to maintain social control and socioemotional wealth prevails over risk aversion, being the relationship between family ownership and leverage more complex and contingent than has been assumed in financial and behavioural models. In addition, this study contributes further evidence on the importance of family reputational intangibles, showing a positive indirect effect on firms' leverage capacity and relating to the gap left by finance theory regarding the value of intangibles for debt, which has meant that their value in reducing information asymmetries in the capital market has been overlooked.
\end{abstract}

Keywords Leverage $\cdot$ Family firm $\cdot$ Information asymmetries $\cdot$ SME $\cdot$ Tangibility

JEL Classification M10 Business Administration-General

Sergio Camisón-Haba

sergio.camison@uv.es

César Camisón

cesar.camison@uv.es

José Antonio Clemente

joseantonio.clemente@unir.net

1 Faculty of Economics, Universitat de València, Av. Tarongers S/N, 46022 Valencia, Spain

2 Faculty of Business and Communication, Universidad Internacional de La Rioja, C/Almansa, 101, 28040 Madrid, Spain 


\section{Introduction}

Among the firm characteristics that affect capital structure, agency theory has placed particular emphasis on the differential effect of the ownership structure (Jensen and Meckling 1976), that has special implications for the family firm (FF), because its distinctive features have a significant impact on leverage (Romano et al. 2001; Chua et al. 2011; Li et al. 2019). Capital structure decisions have attracted growing interest in family business research (Voordeckers et al. 2014; Michiels and Molly 2017), but this literature continues to report contradictory empirical results (Al-Najjar and Hussainey 2011; Schmid 2013). This empirical inconsistency may stem from the heterogeneity naturally inherent in family firms, that has not been adequately analysed in the family business literature (Mensching et al. 2014). The study of family businesses as a set of heterogeneous organizations stands out as one of the most relevant research gaps in the field (Rovelli et al. 2021). Thus, the possible differences in financial behaviour between distinct categories of FF (Habbershon and Williams 1999; Judge 2012; Cruz and Nordqvist 2012; Sciascia et al. 2014) may be behind the inconsistency in the empirical results on the FF effect on leverage. Firm size is a critical variable for the segmentation of the FF population, as the literature has demonstrated its notable influence on the financial behaviour of the FF (Fama and French 2002; Cavalluzzo et al. 2002; Esperança et al. 2003; López-Gracia and Sánchez-Andújar 2007; Van Caneghem and Van Campenhout 2010). This research focuses on the issue of the capital structure decision in the small and medium-sized family firms (SMFF).

Part of the idiosyncratic nature of the SMFF stems from the family ownership. But at the same time, the need to specifically study the financial behaviour of the SMFF is due to its small size, which can lead to it adopting a distinct pattern of behaviour that distinguishes it even from the big FF (Abdulsaleh and Worthington 2013).

However, and despite the unique nature of the SMFF, the research into its leverage has in principle followed same analytical frameworks as those applied to the study of this issue in the corporate world in general, and in big/listed FF in particular (Poutziouris 2001; López-Gracia and Sánchez-Andújar 2007). This theoretical choice comes up against a problem: taking the managerial theory of the firm as the analytical framework.

This theoretical uncertainty surrounds several points that constitute our key research questions. First, we question the extent to which the managerial and behavioural models of the firm help to understand the choice of capital structure in SMFF. Second, it is worth examining the extent to which the practices of financial disclosure and investment in tangible assets are by themselves an effective way for the SMFF to convey a reliable image of the company, thereby reducing information asymmetries, and how this effect translates into the level of leverage. Third, it is appropriate to ask how the capital structure varies with regard to the specific assets that SMFF develop. Lastly, we ask what the most appropriate financial strategy for would be resolving the apparent trade-off between the value of reputational assets for improving the SMFF's competitive position and its ability to take on debt. 
This research confirms that, in the case of the SMFF, the relationship between family ownership and leverage is more complex and contingent than has been assumed in financial and behavioural models. A second set of contributions addresses the particular problem of SMFF capital structure and the contradictions in the attempts to explain it through the classical theory of finance. The third noteworthy contribution relates to the gap left by finance theory regarding the value of intangibles for debt. Lastly, the empirical results reported help fill the existing gap on the implications of the SMFF objective function for strategy and entrepreneurship.

The sample of tourism SMFF is suited for this research because although the tourism industry performs a critical role in the world economy, its ownership structure has received a minor research attention (Yeh 2018). Second, its study is relevant because follows the suggestion from an extant literature to take into consideration the industry characteristics when we examine corporate governance (Guillet and Mattila 2010; Yeh 2013; Yeh and Trejos 2015). The nature of the tourist industry is one founded on experience goods (Nelson 1970), making reputation a key strategic asset for managing information asymmetries. Moreover, tourism firms face a changing environment (Tsai et al. 2011), because they are highly sensitive to uncertain challenges caused by social, political or geographical problems but too linked to economic fluctuations (Ooi et al. 2015). Uncertainty enhances the importance of disclosure practices to gain lenders' confidence. The tourism industry is therefore a particularly appropriate setting for examining the interrelationships between SMFF, information asymmetries and reputation. The Spanish tourism industry is a particularly valuable context in which to investigate this issue. In 2017, Spain became the world leader in tourism. However, its structure is dominated by microenterprises with fewer than 10 employees $(91.1 \%$ of total firms) and by FF (representing 73.4\% of the total) (Camisón and Monfort 2011) This industry has had to face tough adjustment challenges over the past decade to respond to the economic crisis of the last decade, as well as the rapid penetration of large international hotel chains into the Spanish market and the expansion of powerful national chains. These challenges have posed some problems for Spanish tourist SMFF to resolve: (a) the desire to maintain control of the business, which means resorting to debt to cover capital; (b) the growing need for capital for investments to modernize their tangible assets (buildings) and intangible assets (reputation and brand). The choice of the financial structure and leverage therefore constitutes a vital challenge for the survival of Spanish firms in this industry.

Following this introduction, the remainder of the work is structured as follows. A review of the literature on the determining factors of capital structure is examined in the second section and the working hypotheses are proposed in the third section. The methodology, databases, and the measurement of variables included in the regression analysis are presented in the fourth section. The empirical results of the statistical analysis are presented in the fifth section while the sixth section consists of a discussion of the results. The last section includes the conclusions of the study, recommendations for business practice, and a description of the study limitations and future research directions. 


\section{Theoretical background}

\subsection{Capital structure, agency problems and information asymmetries}

A firm's capital structure is the result of a decision about how to finance its operations and its growth, with the combined use of debt and equity. Most firms design their capital structure as a combination of debt and equity to finance their investments in assets and to minimize their capital cost. For this reason, evaluating the costs and benefits associated with the use of debt and equity is a managerial priority (Karadeniz, et al. 2009). The resulting capital structure is usually called leverage. Leverage is the ratio of a firm's debt to its total assets.

Theories on the relevance of capital structure are based on the assumption that financial decisions are made with the aim of maximizing value, within the context of a large managerial firm characterized by dispersed ownership among many small shareholders, with control concentrated in the hands of a few professional managers, and the regulation of commercial relations through agency contracts. The first type of companies on which their theoretical predictions were tested was, logically, large firms organized according to the managerial model. It is within this context that the agency problem is defined (Jensen and Meckling 1976); this problem can arise either between shareholders and creditors (agency costs of debt) or between shareholders and managers (agency costs of equity). The sources of the agency problem are the separation of roles between agents, which leads to a divergence in their individual incentives, and opportunistic behaviour stemming from incomplete and/or illegal contracts and a lack of ethical decision-making. Myers (2001) goes on to say that "perfect alignment is implausible in theory and impossible in practice".

The main friction in firms' contractual network is information asymmetries, which are at the root of agency problems (Jensen and Meckling 1976). Asymmetric information arises when information is unequally distributed between parties involved in a market transaction (Akerlof 1970; Stiglitz 2002); this information may concern (a) the quality of the investment projects that the company is seeking to finance; or (b) the use the debtor plans to make of the external resources to be received (Leland and Pyle 1977; Stiglitz and Weiss 1981; Stiglitz 1988). Asymmetric information plays a central role in the analysis of the relationships between firm and lenders and in determining the capital structure. This information imbalance between shareholders/managers and creditors, creates uncertainty in financial negotiations, problems in accessing quality external capital and/or lenders stipulating certain conditions to compensate for their informational disadvantage, such as an increase in the cost of the capital or a request for additional guarantees (Stulz 1990). At the same time, debt can be used as a means of reducing agency costs between shareholders and managers (Sibilkov 2009). The risk of opportunistic behaviour by managers will prompt shareholders to look for mechanisms to monitor and control the managers' actions, which can be very expensive. A higher level of debt can alleviate a potential conflict of interest between managers and shareholders (Jensen and Meckling 1976) when discouraging managers 
from building empires in firms with high levels of free cash flow that could be expropriated otherwise (Jensen 1986; Stulz 1990). The design of the capital structure will thus be governed by the objective of minimizing the total agency costs associated with the information asymmetries.

\subsection{Agency problems and signalling and collateralization effects}

Firms can develop a range of actions to reduce agency problems, including methods of financing, monitoring and signalling (Myers 1984). If the objective is to reduce information asymmetries and thus mitigate agency problems, then sending credible signals to creditors becomes a priority (Fan and Wong 2005). Methods for doing so include signalling initiatives such as delivering more verifiable and publicly-available information to potential creditors; and collateralization initiatives, such as providing more guarantees in the form of tangible assets. The effectiveness of financial disclosure as a means of mitigating information asymmetries and enabling access to debt has been called into doubt (Wallman 1995; Lev and Zarowin 1999). The risk of lenders expropriating shareholders' wealth encourages the firm to supply better quality information (Jensen and Meckling 1976; Wu et al. 2007a, b; Cerqueiro et al. 2016). When it comes to communicating the state of its business to outside stakeholders, financial statements are the most important element of a firm's disclosure policy (Beuselinck et al. 2008: 616). The accounting and finance literature holds that the disclosure of financial information in accordance with international accounting standards helps clear up any doubts that creditors may have about the firm's solvency and its business prospects. This reduction in perceived risk in the supply of capital would help firms that disclose more information of higher quality through these channels to secure more financing at a lower cost (Larrán and García-Mecca 2004: 82). Finance theories have attributed the utmost importance to the nature of tangible assets given their potential collateral value, and the guarantee they thus offer to external providers of capital; this is the case both at the theoretical level (Stiglitz and Weiss 1981; Myers 1984; Myers and Majluf 1984) and in the empirical evidence on the managerial company (Frank and Goyal 2009; Sony and Bhaduri 2018; Danso et al. 2019). Conversely, the same theories have downplayed the collateral value of intangibles because they have low residual value and are difficult to divest (Long and Malitz 1985; Gonzalez and González 2008: Frank and Goyal 2009; Campello and Giambona 2011).

\subsection{Agency problems, socioemotional capital and assets structure in family firms}

The FF literature has attempted to pinpoint the specific features derived from the family ownership structure in terms of the agency costs associated with information asymmetries, with the financial disclosure practices that the firms adopt to minimize these asymmetries, and with guarantees offered through the collateralization of assets in order to clear up any such uncertainty (Poutziouris 2001; López-Gracia and Sánchez-Andújar 2007). Another stream of the literature has attempted to explain the choice of leverage in terms of a trade-off between the tax savings achieved 
through debt and the costs of financial distress and possible bankruptcy (Romano et al. 2001).

The specific research into the issue of FF capital structure became established with SEW (Wiseman and Gómez-Mejía 1998; Gómez-Mejía et al. 2007). This approach highlights some of the unique characteristics of FFs that determine their leverage. SEW highlights the importance of non-financial aims and values and shows how these are prioritized above value maximization for owners. These nonfinancial aspects include preserving the power of the family dynasty through control of the FFs' capital, intrinsic motivations such as emotional needs, that drive to giving preference to family members in positions of managerial responsibility, maintaining the family identity and culture (Koropp et al. 2014) or keeping the peace and family harmony. All these elements feed into the socioemotional wealth that the firm seeks to conserve. In addition, family ties should reduce the risks of opportunistic behaviour and increase the occurrence of altruistic behaviour. Together, unlike nonFF, FF shows a marked commitment to long-term survival. The profile of the family thus becomes that of a long-term investor seeking to transfer control and ownership to the following generation (Anderson et al. 2003). The model of the firm shaped by SEW therefore has a clear behavioural cast, in the sense that it holds that financial decisions are guided more by emotions, values and mental frameworks than by rationality, as is advocated by the behavioural finance approach (Kahneman and Tversky 1979; Thaler 1993).

According to the SEW, the hierarchy of financial decisions wherein internally-generated funds are prioritized over debt, with external equity left as the last option can be explained by the desire to maintain family control. However, SMEs and FF find it harder to prioritize internal funds due to the restriction imposed by the family's available capital base, which limits the possibility of an increase in equity capital. In addition, there is a severe drain on internal financing every time the company has to undergo a succession process (Molly et al. 2010; Koropp et al. 2013a). Therefore, the non-financial objectives of FF and their ability to rely on internal financing should lead to a positive relationship between family control and the firm's debt level. However, altruistic behaviour, the common interest in the firm's long-term survival and the goal of ensuring that the family legacy is passed on to ensure the well-being of family members (Becker 1981; Bertrand and Schoar 2006) can increase the perceived risk of defaulting on debt. If this prediction were to be confirmed, FF should opt for more conservative financial policies that substantially limit their debt level (Miller and Le Breton-Miller 2006). Strebulaev and Yang (2013: 19), based on an analysis of large FF over the period 1992-2009, concluded that FF use debt more conservatively. Therefore, the behavioural model of the FF, which identifies family ownership as the main predictor of the capital structure, gets stuck in the trade-off between the FF's desire to maintain control (which fosters the use of debt) and its risk aversion (which encourages prudent attitudes towards debt) (González et al. 2013; Schmid 2013; Burgstaller and Wagner 2015). This inconsistency has been consistently noted in the literature. While some authors (Wu et al. 2007a; López-Delgado and Diéguez-Soto 2020) find higher leverage in FF, other studies report the opposite (Poutziouris 2002; Gallo et al. 2004; 
Ramalho and Silva 2009; Ampenberger et al. 2013). There are even some studies that report no significant differences or find the differences to be contingent on the effect of other variables (López-Gracia and Sánchez Andújar 2007; Bjuggren et al. 2012; Li et al. 2019).

The importance of investments in specific assets as determinants of an FF's level of leverage makes it necessary to include in the theoretical modelling the strategic decisions taken by the firm to develop these assets. The relationship between the FF's debt level and asset tangibility or intangibility can be better understood if we recall the key role played by resources and capabilities in a firm's success. The fundamental strategic theory in this respect is the RBV (Barney 1986 1991; Grant 1991; Peteraf 1993) along with its derivative in the field of the FF, the literature on the concept of (Habbershon and Williams 1999; Habbershon et al. 2003; Habbershon 2006; Pearson et al. 2008). This term denotes the unique set of resources and capabilities that an FF possesses because of the interaction of different systems: the family as a whole, the individual family members, and the business. In other words, familiness refers to the resources and capabilities stemming from the involvement of the owning family; as such, it can be key to the analysis of the relationship between FF advantages and outcomes (Camisón 2019).

The resources are "stocks of available factors that are owned or controlled by the company" (Amit and Schoemaker 1993: 35). The quantity and quality of the accumulated resources largely determine what firms can do, as they place restrictions on activities and processes (Grant 1991: 119). Most resources are tangible assets, understood as the physical capital on which the firm can establish relationships of ownership or economic control, and which can function independently of people (Barney 1991). That said, few resources are productive when used independently. Capabilities are groups of resources skilfully managed in a coordinated manner and with a specific purpose or function (Eriksen and Mikkelsen 1996: 58). RBV emphasizes that sustainable competitive advantages stem basically from complementary and specialized resources in form of capabilities, which are scarce, lasting, inimitable and of limited transferability. It is the complex and collective nature of capabilities that makes them strategically advantageous (Priem and Butler 2001). All capabilities are intangible assets. This is why the RBV underscores the value of intangibles as a source of sustainable competitive advantage (Hall 1992, 1993).

Of particular interest for the purposes of our research are the intangibles that arise from the relationship the firm establishes with its customers and other external stakeholders, through its products, its service history and its credibility built up through its actions and decisions. These intangibles can be classified under the label of reputation. Reputation is an intangible asset that is built on the firm's ability to meet the expectations of its stakeholders (Origgi 2018) and on the information that the firm's external stakeholders obtain about it (Fombrun 1996 2001; Zaheer and Bell 2005). This is a relevant concept for our research questions, as reputation can help paint an accurate picture of the strength of the firm, one that goes beyond the limitations inherent in financial disclosure, which exerts an effect on lenders. 


\section{Hypotheses}

SMFF do not tend to suffer from agency problems between managers and shareholders because managers are members of the family. The complete overlap of management and ownership eradicates the agency costs arising from the free use of cash flow by management for purposes other than creating value for shareholders (López-Gracia and Sánchez-Andújar 2007). Reducing this risk makes the use of debt less attractive as a means of disciplining management (Jensen 1986; Stulz 1990). But even when there is a separation between the two roles, SMFF, with their concentrated and undiversified ownership structure, display fewer agency conflicts between managers and owners; this is because large owners attach greater importance to supervising the managers' work as part of their objective of maintaining business control across generations (Anderson et al. 2003; Miller and Le Breton-Miller 2005; Villalonga and Amit 2006; Andres 2008). In addition, managers will resist the temptation to engage in opportunistic behaviour that runs counter to the interests of large owners, whose power could harm their professional career (Fama and Jensen 1983). There are no major agency problems among the owners in SMFF. The concentrated ownership in FF thus entails a disadvantage that has been observed for firms in general (Shleifer and Vishny 1997): the risk of possible expropriation of minority shareholders by large owners imposing their personal interests (Setia-Atmaja et al. 2009). However, family stakeholders usually have homogeneous interests due to the fact they share a family culture inherited from the founders. Therefore, SMFF debt does not play a relevant role in disciplining managers (Ampenberger et al. 2013) and/or large owners. Internal conflicts in the SMFF may be caused by family members being appointed as managers or hired as workers without any assurance they have the necessary skills (Shigeru 2017). The entrenchment effect creates motives for seeking private benefits (Demsetz 1983; Fama and Jensen 1983). Debt can then play an important role in disciplining the family itself (Setia-Atmaja et al. 2009).

Conversely, the risk of financial distress or bankruptcy is especially worrying for SMFF because they generally have large, undiversified ownership stakes. SMFF thus tend to adopt concentrated capital structures, dominated by large shareholders who focus most of their wealth in a single business (Shleifer and Vishny 1997; Andres 2008). This concentration of family wealth is likely to encourage prudent attitudes towards debt. In addition, the strong culture of prioritizing intergenerational survival found among family owners (Anderson et al. 2003), can make the FF more financially conservative. This is typically observed in big FF (Miller and Le Breton-Miller 2006; Strebulaev and Yang 2013). Nevertheless, the SMFF is often forced to abandon this financial prudence as selffinancing and family equity can only meet the firm's growing investment needs to a limited extent. The more necessary it is to maintain family harmony, the greater this restriction will be, coming either at the cost of a greater distribution of dividends or at the cost of buying back shares from family members who wish to leave the business. There is a severe drain on internal financing every time the company has to undergo a succession process (Molly et al. 2010; Koropp et al. 
2013a). Consequently, the firm could show a greater propensity for taking on debt, as it does not compromise political rights and enables a level of financing beyond the possibilities offered by retained earnings and the accumulated family wealth. In any case, the relationship between family ownership and leverage is highly contingent on the context of agency contracts, family contracts (often through family protocols) and the firm's strategic plan.

\subsection{Agency problems, family commitment, information asymmetries and collateral tangible requirements}

In regard to the first element of this context, concerning agency contracts, the literature agrees that SMEs may have more difficulties taking on debt as they are afflicted by the typical problems associated with information asymmetries (Ang 1992; Binks and Ennew 1994; Van Caneghem and Van Campenhout 2010). The literature based on pecking-order theory also emphasizes the importance of the information asymmetries involved in the agency problems of the SMFF (Berger and Udell 1995 1998; Cavalluzzo and Cavalluzzo 1998; Wu et al. 2007a, b); and in the methods these organizations adopt to reduce agency costs by improving the public disclosure of verified financial information (Berger and Udell 1995; Wu et al. 2007a, b).

The adequacy and reliability of the financial information disclosed and whether it is a faithful reflection of a firm's assets is increasingly being called into question, in light of the growing dissociation between market price, profitability, profit, cash flow and book value (Wallman 1995: 84; Lev and Zarowin 1999) and the long list of malpractices in corporate disclosure (Farvaque et al. 2011). Doubt has also been cast on the specific case of SMEs (Van Tendoloo and Vanstraelen 2008), because they disclose less detailed information (Van Caneghem and Van Campenhout 2010), they lack credit records (Berger and Udell 1995 1998), and their publicly-available information is not audited (Wu et al. 2007a, b; Chua et al. 2011), meaning it is considered to be of lower quality (Pettit and Singer 1985). As such, stakeholders are not assured of the absence of fraud (Van Tendoloo and Vanstraelen 2008). Berger and Udell (1998: 616) refer to "acutely informationally opaque" small firms. In the specific case of SMFF, the entrenchment effect creates motives for seeking private benefits and opens up the possibility of opportunistic manipulations of financial statements (Ding et al. 2011). Li et al. (2019) report that for SMFF even external auditing does not significantly reduce the cost of debt when there is family involvement. Thus, we should not expect a positive relationship between publicly-disclosed information and the debt level; nor do we expect publicly-disclosed financial information to have a significant moderating effect on the relationship between SMFF and debt.

When information asymmetries are addressed in order to mitigate agency problems, at the same time as debt levels rise, lenders become more impatient to see the expected return on investments and begin to contractually require companies to put up collateral assets that attest to their solvency (Stiglitz and Weiss 1981; Coco 2000). In terms of the quality of the collateral used to cover the lender's risk, it must be able to be sold for a predictable value and rapidly generate cash and liquidity flows to ensure the recovery of the investment. The timing of the 
flow of income generated by the investment-which has to cover the payments to the principal as well as the financing cost—can vary according to the nature of asset, but in general the financial results generated by tangible assets can be seen in a shorter timeframe, as these investments mature more rapidly. Lenders' impatience prompts them to prioritize granting loans for investments in tangible assets, and they may even explicitly rule out the use of intangible assets as collateral (Long and Malitz 1985). The liquidity requirement means that it must be possible to sell the collateral assets on the market to enable the company to meet its payment obligations in the event of insufficient cash flows from the investment; and tangible assets aptly meet this requirement (Modugu 2013). Tangible assets often offer a higher net asset value in the event of bankruptcy because they can be sold off individually. Therefore, the possession of tangible assets with collateral value can eliminate asymmetries, reduce the risks perceived by lenders and contribute positively to a higher level of debt (Myers and Majluf 1984; Rajan and Zingales 1995; Booth et al. 2001).

An issue with previous theoretical modelling is that it has tended to focus only on the individual effects of the endowment of tangible assets. (Ono and Uesegi 2009; Odit and Gobardhun 2011). However, we should not expect a positive relationship between tangible collateral assets and the debt level in small and medium-sized firms. These firms always have problems with the collateralization of their tangible assets, due to their lower capital intensity, and the fact that their fixed assets tend to be relatively older and less technologically modern. Lenders' distrust of the liquidating value of small and medium-sized firm's tangible assets adversely affects their willingness to invest. However, it is evident that it is precisely the higher degree of information transparency associated with these factors (Alchian and Demsetz 1972; Lippman and Rumelt 1982) which clears up any doubts that could diminish the collateral value of such assets in SMFF. In these firms, in order to reduce information asymmetries, tangible collateral assets must be combined with a policy of publicly disclosing comprehensive, detailed financial information. Based on the above arguments, the following hypothesis can be posited:

Hypothesis 1 The relative amount of tangible assets on balance sheet will positively moderate the effect of publicly-available financial information on the small and medium-sized family firm's debt level.

Lenders' demand for collateral guarantees from SMEs could be expected to increase when they are FF, because of the uncertainty associated with the parents' altruism. The emotional basis underpinning the appointment of managers in the SMFF, since they are selected from among the family members, means that the family may tolerate and even cover up problems such as "free riding" (Bruce and Waldman 1990), the entrenchment of ineffective managers (Morck et al. 1998) or predatory managers (Morck and Yeung 2003). In SMFF, these risks may lead to a lack of competencies or reduce the drive to work to improve the firm's wealth creation potential (Schulze et al. 2003). Lenders' natural reaction would thus be 
to stipulate higher collateral requirements when dealing with SMFF, although this additional guarantee may not sufficiently boost their confidence as the value of the assets can deteriorate with ineffective management. The tangibility of assets would therefore not be enough for them to have a positive influence on the relationship between family ownership and leverage. Some studies seem to confirm this (e.g., González et al. 2013), reporting a negative effect of family management on leverage.

Family altruism coupled with the effect of the family's non-diversified investment portfolio also serve to temper managers' self-interest and prioritize long-term commitment (Ang 1992). This objective function leads to lower cash flow volatility and risk of default (Bopaiah 1998), and thus a better alignment of interests between the SMFF and its creditors (Voordeckers and Steijvers 2006). The result is more frequent personal commitment by family owners providing personal collateral or guarantees, to the point of losing the separation between family and business risks (Ang et al. 1995). Some studies even point to the bank lending policies that tend to prioritize the guarantee provided by the owners' wealth over the firm's repayment capacity (e.g., Gallo and Vilaseca 1996; Mishra and McConaughy 1999). SMFF thus have to make extra efforts to ensure information transparency and providing personal and business tangible assets as a signal to lenders of their willingness to share the risks of the financing decision (Audretsch and Elston 2010). This leads to the following hypothesis:

Hypothesis 2 Continuous improvement in the provision of tangible assets and the publicly-available financial information positively moderates the relationship between family ownership and the SMFF's debt level.

\subsection{Agency problems, family commitment, information asymmetries and intangibles}

The adequacy and reliability of the financial information disclosed is also increasingly being called into question because there are no corresponding financial statements for most intangible assets (Wallman 1995: 84; Larrán and Rees 2003; Lev 2016; Ernst and Young 2019). The vast majority of intangibles are informationbased capabilities, which can be classified as invisible assets as they do not feature in the disclosed financial information (Govindarajan et al. 2018). The consequence of this omission has been to further strengthen the already weakened relationship between accounting information, credit decisions and investment, and the accounting information has lost its relevance in explaining the creditors' decision making behaviour (Lev and Sougiannis 1996; Barth and Clinch 1998; Brown et al. 1999; Francis and Schipper 1999; Hail 2013; Allen and Cote 2005). Therefore, there are high information asymmetries between firms and lenders in investment projects involving intangible assets, which means it is more difficult use intangibles that are easily verifiable by third parties to improve their confidence in the firm. At the same time, the nature of intangible assets means that putting a value on them is a complex task; moreover, there are no corresponding financial statements for most 
such elements. Therefore, by itself, a firm's wealth in intangible assets is not really reflected in the value of these assets as collateral for debt, asymmetries. For these reasons, we should not expect a positive relationship between investment in intangible assets and leverage; nor should we expect these assets to have a significant moderating effect on the relationship between the SMFF and debt.

However, as financial information disclosure becomes less relevant firms are under pressure to go beyond the legally-required disclosures and provide information relating to strategy, resources and capabilities (Buigues et al. 2000; Hand and Lev 2003). The expanding scope of disclosures of non-financial information is also a consequence of a growing need for firms to meet stakeholders' informational requirements, so that they are better informed when making their investment, purchase or activism decisions. For market stakeholders, the key non-financial information is that on intangible assets (Hall 1992; Grant 1991; Holland 2001). The share of intangible assets in firms' total market value continues to grow (Blair and Wallman 2001). Intangibles play a decisive role in determining the information available on market conditions and the firm's growth potential.

Stakeholders' assessment of the company to which they are linked is primarily manifested through its reputation (Hall 1992; Barney 1991). Reputation is not constructed with raw information; rather, the information is filtered and validated by other users whose opinions we trust and by secondary stakeholders providing information that may either corroborate or undermine that issued by the company. In other words, there is tacit knowledge distributed among different actors, which the company does not control, and which can affect its reputation. Reputation is not constructed with raw information about the firm that stakeholders find for themselves (Fombrun 1996 2001; Zaheer and Bell 2005); rather, the information is filtered and validated by other users whose opinions we trust and by secondary stakeholders providing information that may either corroborate or undermine that issued by firm (Origgi 2018). This information may even go so far as to cancel out the positive effects of transparency between the firm and the market on the firm's competitive position (Kossovsky 2010) or to reduce financing costs (Kordsachia 2020). It is not easy to gain a reputation for quality, the loyalty of suppliers or the trust of customers. Complex efforts are required over a lengthy period in order to cultivate these elements, demonstrating the honesty of the organization and the reliability of its products. Reputation is therefore a key element in minimizing agency costs (Tran 2019) and generating sufficient confidence in markets to enable the firm to access external capital, if the firm is able to convey and effectively manage all the information in circulation on which its reputation is based.

The only way to overcome the problems of access to debt due to the low value of intangible assets as collateral, is to reassure financial institutions about the firm's capacity to return the credit with the income generated by its operations. Providing information that attests to the firm's competitiveness, its solvency as a functioning company and the robustness of its cash-flow generation capacity could offset the disadvantages stemming from the low liquidation value of its intangible asset investments (Holland 2001). Reputational intangibles still have no collateral value because they are not assets that can be sold independently of the rest of the company (Rindova et al. 2010). However, to the extent that they 
support the firm's competitive strength, they help potential providers of capital feel more confident that the investments undertaken with the funds contributed will yield the expected results. Therefore, the firm's reputation complements the financial information it discloses by providing the non-financial values missing from the accounting statements, which improve the firm's competitiveness and help secure investment capital on attractive terms. The firm attests to the reasons for confidence and helps lenders to form an accurate and trustworthy image of the strength of the firm, one that goes beyond the limitations inherent in financial disclosure, which exerts an effect on lenders.

Consequently, we can propose the following hypothesis:

Hypothesis 3 A firm's wealth in reputation assets that are off-balance-sheet but have a known market value will positively moderate the effect of publicly-available financial information on the small and medium-sized family firm's debt level.

However, the possible obstacles stemming from such a policy do not seem to be a solid argument in light of the empirical evidence on the lower cost of SMFF debt (Anderson et al. 2003), especially when the lenders' fear of expropriation by controlling shareholders is dispelled (Boubakri and Ghouma 2010; Yen et al. 2015). These results are consistent with banks' attitudes towards SMFF and how they are reflected in the loan terms. The overall conclusion is that bank's view SMFF more positively and have greater confidence in them because they perceive fewer agency problems (Bopaiah 1998) and information asymmetries (Song and Wang 2013). As such, SMFF can secure access to credit under better conditions (Bopaiah 1998), especially in the long term (Croci et al. 2011).

Regarding publicly-available information, if there is a predominant ownership core that is stable and well known to the banks, this can help establish a sustained long-term, personal and well-informed relationships of trust between family managers and the credit institution (Song and Wang 2013). This social capital helping to gain access to credit (Chua et al. 2011) is reinforced by the lenders' knowledge of the owning family's credit history and business reputation, as well as by the overriding commitment of SMFF to keeping the business going (survival objective). Family ownership is a natural source of reputational intangibles, which convey complete information about the firm's historical success in solving problems and achieving an acceptable standard in the profitability-risk equation. Widespread recognition of the family and business names, the family's pride in being reflected in the corporate image, and their concern for protecting their family and maintaining their good reputation in their local area where it has strong social roots, are all distinctive values of SMFF. These values create confidence that firms will honour their agreements by precluding policies involving the expropriation of creditors. Financial information is thus augmented by reputation about the owning family, thereby helping to reduce information asymmetries. Assuaging uncertainty facilitates lower costs of debt (Anderson et al. 2003) and enables SMFF to raise their leverage. We therefore hypothesize: 
Hypothesis 4 Continuous improvement of the family reputation and of the publicly-available financial information positively moderates the relationship between family ownership and the SMFF's debt level.

The financial literature has also addressed other variables that a priori could be assumed to affect the firm's capital structure, such as growth (Esperança et al. 2003; Van Caneghem and Van Campenhout 2010), average leverage in the industry (Van Caneghem and Van Campenhout 2010), size (Fama and French 2002; Esperança et al. 2003), age (Esperança et al. 2003; Van Caneghem and Van Campenhout 2010) and profitability (Jensen 1986; Myers 2001; Fama and French 2002; Pindado et al. 2006; Van Caneghem and Van Campenhout 2010). Finally, dummy variables have been included for the different tourism sub-sectors and for the years of the sample, to capture contextual effects.

Figure 1 presents the model that depicts the hypothesized relationships among family ownership, investment in tangible and intangible assets, financial disclosure and leverage.

\section{Methodology}

\subsection{Databases}

The database we use combines information from primary and secondary sources on the Spanish tourism industry. The sample was selected from the entire population of Spanish tourism companies in the 2008 Central Companies Directory (DIRCE) compiled by the National Institute of Statistics. According to this census, there was a total population of approximately 140,900 tourism businesses in 2008 . The initial sample of 8,148 firms was selected using a stratified random sampling procedure

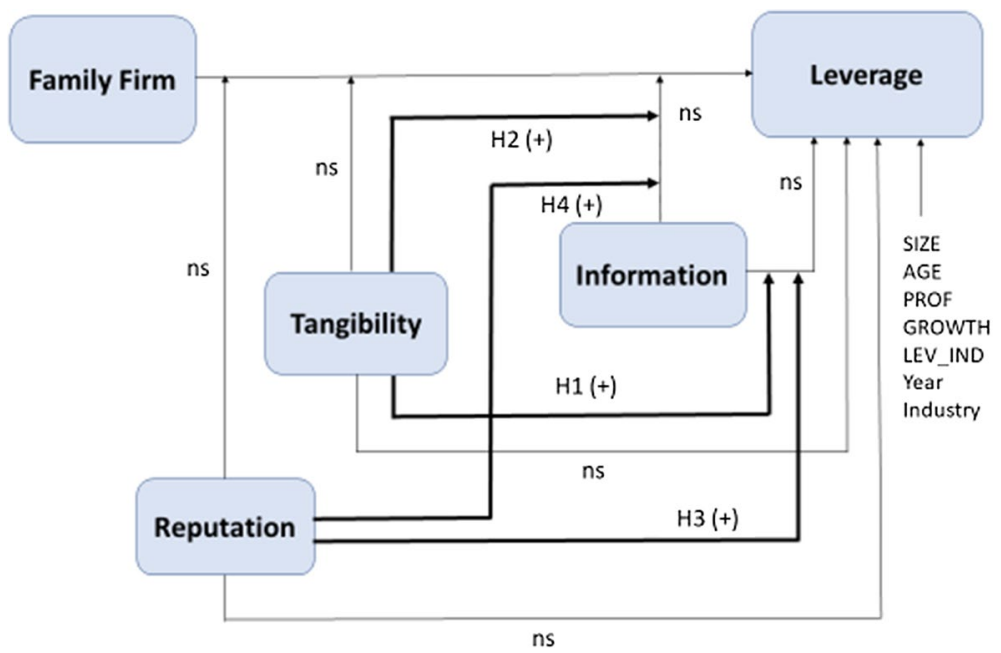

Fig. 1 Theoretical model 
with proportional allocation to ensure the representativeness of the sample in terms of activity (considering four groups), size (taking the number of employees as a measure of firm size) and location. After the initial field research work, ${ }^{1}$ the result was a sample of 1019 companies successfully contacted, that represent a confidence level of $95 \%$ and an interval of $\pm 3.1 \%$.

On this final sample of 1,019 companies, we conducted a survey that allowed us to create a database with data from a questionnaire and personal interview with the firms' CEO, conducted by an independent specialized firm. The total questionnaire contains 576 items, which collect information about competitiveness, performance, the environment, the ownership structure, the type of shareholders, and the firm's portfolio of resources and capabilities. A set of recommended survey procedures involving a modified version of Dillman's Total Design Method (1978) was used to correct the problems associated with questionnaires as a data collection method, and to improve the response rate and the quality of the information. The field work was carried out between December 2009 and March 2010.

Additionally, we searched the Sistema de Análisis de Balances Ibéricos (SABI), a database managed by Bureau Van Dijk, to find complete financial information on firms in the sample from 2008 to 2016. The SABI database compiles the financial information annually submitted by Spanish companies in the Commercial Register. The data on Information, Asset Tangibility and Leverage were sourced from this database, as well as the data on our control variables. Since SABI does not provide information for all the companies from the final sample of 1019 companies, together with the fact that we focused on companies that can be classified as small and medium-sized firms according to the official European Union criterion (less than 500 employees), we ended up with a database of 543 companies, of which 165 are non-FF and 378 are FF. This gives a final sample of 4,887 observations that cover the period 2008-2016. Using a series of standard filters, any observations presenting anomalous values in their financial statements or in the calculated ratios were removed from the final sample to prevent distortions in the results.

\subsection{Variables}

In this section, we describe the independent and dependent variables used in our baseline model of financial structure and its determinants in FF. In order to mitigate the effect of outliers, all the variables are winsorized at $0.5 \%$ in each tail of the distribution.

Leverage (LEV): The dependent variable, LEV, is defined as the ratio of longterm plus short-term financial debt (excluding trade credit and other non-debt liabilities) to total assets (Miller et al. 2007; Van Caneghem and Van Campenhout 2010). Following the literature (Lin et al. 2008; Friend and Lang 1988), we exclude trade credit for several reasons: it relates to transaction purposes rather than financing

\footnotetext{
1 The field research work involved negative responses, contacts not achieved, non-compliance with requirements, and not activity.
} 
(Tse and Rodgers 2011), and it is influenced by industry issues (Rajan and Zingales 1995).

Family firm (FF): We consider a company to be an FF if the founder and/or their descendants hold majority ownership and control the strategic decisions (Handler 1989; Shanker and Astrachan 1996). The family's minimum ownership stake has been set at $51 \%$ in private firms and $25 \%$ in public firms (the criterion established by the European Family Businesses Group and the Family Business Network) (see Camisón and Monfort 2011: 59). Thus, we construct a dummy variable, FF, that equals 1 if the company meets the above criterion, and 0 otherwise.

Information (Q): Following Gregory et al. (2005) and Van Caneghem and Van Campenhout (2010), we measure the explanatory variable related to the amount of publicly-available financial information through a proxy capturing the level of detail in the financial statement. Spanish firms must file their financial statements according to mandatory prescribed formats which define the information to be disclosed and the concept and measures of every item. We use a dummy variable, Q, which equals 1 if the company has used the normal format, and 0 otherwise. The more abbreviated financial statements have a simpler format, and the information is less disaggregated. Additionally, when firms are permitted to use abbreviated balance sheets, cash flow and equity statements are not mandatory. Financial statements for small firms only include the balance sheet statement, income statement and notes. We obtain the data for that variable from SABI.

Tangibility (TANG): Tangibility (TANG) is defined as the ratio of tangible assets (net fixed assets) to total assets.

Reputation (REPUT): Our measure of intangible assets is a construct based on the first factor from a factor analysis of five aspects (Acock 2013; Le Breton-Miller et al. 2011). ${ }^{2}$ The aspects are company reputation, brand reputation, customer satisfaction, quality reputation and service quality. These aspects are measured on a 7-point Likert scale (where 1 means "much worse" than competitors and 7 "much better"). The empirical data for measuring the abovementioned aspects was obtained from the questionary answered by the firms' CEO.

For control variables, we apply the following commonly-used proxies (Van Caneghem and Van Campenhout 2010). Size (SIZE) is measured as the natural logarithm of total assets. Age (AGE) is defined as the natural logarithm of the number of years since the creation of the firm. Profitability (PROF) is measured as earnings before interest and taxes (EBIT) divided by total assets. Growth (GROWTH) is measured as the current number of employees less the number of employees in 2008, divided by the number of employees in 2008. Industry (LEV_IND) is defined as the median leverage for each sub-sector and year, according to the type of tourist activity. We also use sub-sector dummies (instead of industry dummies) and year dummies. Table 1 summarizes the descriptive statistics of the variables and Table 2 presents the corresponding correlation matrix.

\footnotetext{
2 As a robustness check, we also measure this variable using a mean score for the same aspects (BenAmar, Francoeur, Hafsi and Labelle 2013; Acock 2013). The robustness results, available under request, are quantitatively and qualitatively similar to the main results.
} 
Table 1 Descriptive statistics

\begin{tabular}{llllll}
\hline & Obs & Mean & S.D & Min. & Max \\
\hline Leverage & 2298 & 0.47 & 0.44 & 0.00 & 3.61 \\
Family firm & 4887 & 0.70 & 0.46 & 0 & 1 \\
Information & 3598 & 0.17 & 0.38 & 0 & 1 \\
Tangibility & 3441 & 0.44 & 0.32 & 0.00 & 0.99 \\
Reputation & 4302 & 0.00 & 1 & -2.66 & 1.81 \\
Size & 3598 & 14.19 & 2.22 & 8.77 & 20.94 \\
Age & 3533 & 2.71 & 0.91 & 0 & 5.11 \\
Profitability & 3584 & -0.01 & 0.23 & -2.00 & 0.56 \\
Growth & 2963 & 0.11 & 1.34 & -0.90 & 16 \\
Industry & 4887 & 0.43 & 0.10 & 0.19 & 0.67 \\
Control & 4887 & 0.15 & 0.35 & 0 & 1 \\
Risk & 3598 & 1.39 & 2.72 & -15.89 & 13.05 \\
\hline
\end{tabular}

\subsection{Data exploitation techniques}

We use the following model to test our hypotheses:

$$
\begin{aligned}
L E V_{i t}= & \beta_{0}+\beta_{1} \cdot F F_{i t}+\beta_{2} \cdot Q_{i t}+\beta_{3} \cdot \mathrm{TANG} \\
& +\beta_{6} \cdot F F_{i t} \cdot \beta_{4} \cdot R E P U G_{i t}+\beta_{7} \cdot F F_{i t} \cdot R E P U T_{i t}+\beta_{8} \cdot F F_{i t} \cdot Q_{i t} \cdot T A N G_{i t} \\
& +\beta_{9} \cdot Q_{i t} \cdot R E P U T_{i t}+\beta_{10} \cdot Q_{i t} \cdot T A N G_{i t} \cdot F F_{i t}++\beta_{11} \cdot Q_{i t} \cdot \\
& R E P U T_{i t} \cdot F F_{i t}+\beta_{12} \cdot S I Z E_{i t}+\beta_{13} \cdot A G E_{i t}+\beta_{14} \cdot P R O F_{i t} \\
& +\beta_{15} \cdot G R O W T H_{i t}+\beta_{16} \cdot L E V_{-} I N D_{i t}+\varepsilon_{i t}
\end{aligned}
$$

Following the literature (Kim et al. 2016; García et al. 2016; Lei et al. 2018), we estimate our model using panel data with year-fixed effects to control for yearspecific conditions and robust two-way clustered standard errors at both the firm and year levels (Petersen 2009). Results from the panel regression model are reported in Table 3. Analysis of the plots of interaction effects (Fig. 2) enables a more precise interpretation of the economic meaning of the significant coefficients obtained from the statistical model (Uhlaner et al. 2015).

In order to check our main results, we conduct several robustness tests for control for the potential endogeneity of the variables (Miller et al. 2007). For the FF variable, we use treatment effect regressions and use the etregress Stata command (two-step consistent estimator). In this estimation, we first conduct a probit regression where the FF variable is the independent variable, and the controls are the same as those used in our main model, along with another two additional variables commonly used in the literature (Villalonga and Amit 2006; Anderson and Reeb 2003; Miller et al. 2011; Pindado et al. 2011; Schmid 2013; Bouzgarrou and Navatte 2013); namely RISK (the Altman 1968 Z-Score) and the control mechanism of the FF (CONTROL). For the Reputation variable we rely on instrumental variables (González et al. 2013; Bouzgarrou and Navatte 2013) due to the continuous nature of this variable, and use the variables added in the first stage of 


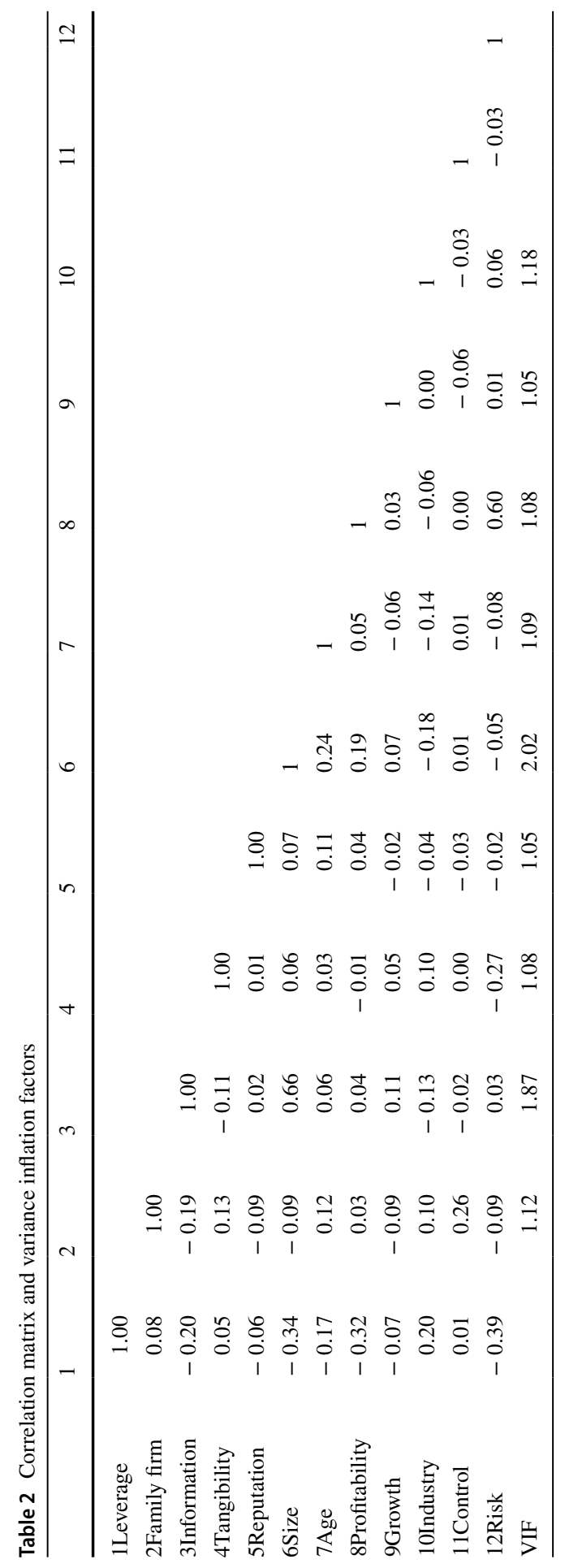









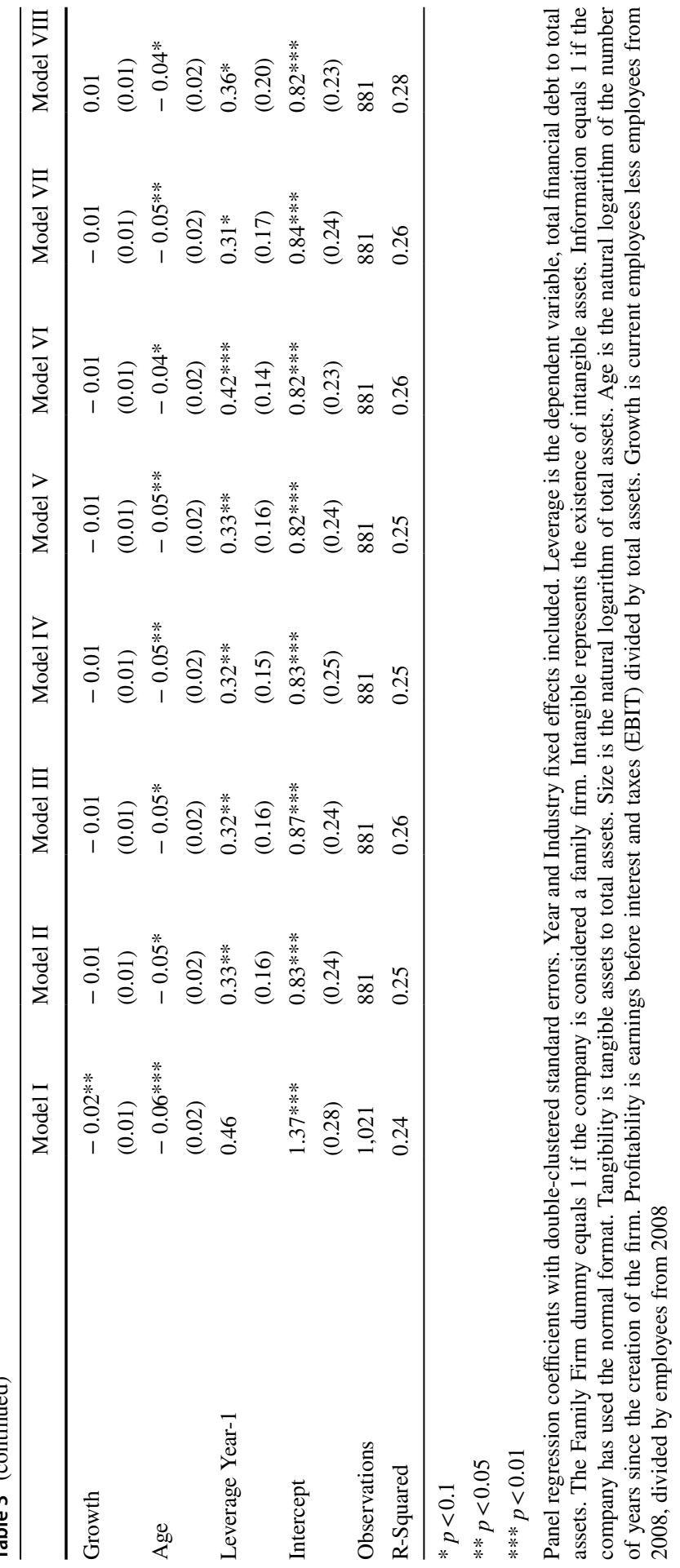




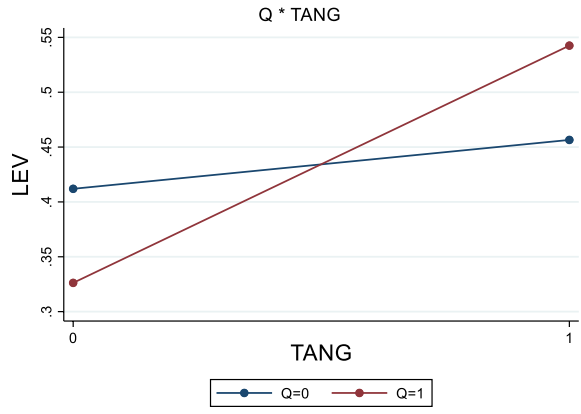

Figure 2.1 Interaction of Information and Tangibility.

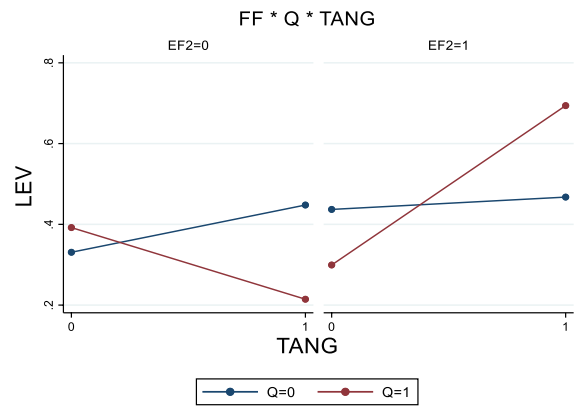

Figure 2.3 Interaction of Information with Family Firm with Tangibility.

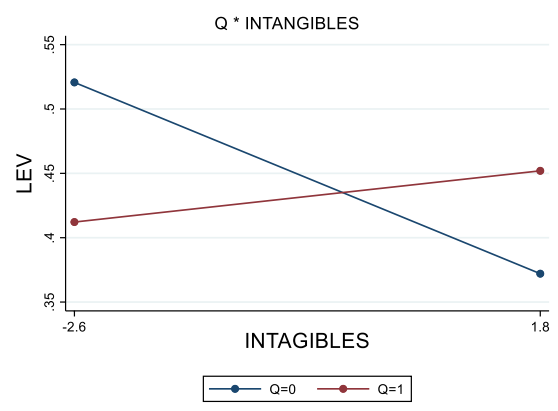

Figure 2.2 Interaction of Information with Intangibles.



Figure 2.4 Interaction of Information with Family Firm with Intangibles.

Fig. 2 Plot of significant interaction effects. 2.1 Interaction of information and tangibility. 2.2 interaction of information with Intangibles. 2.3 Interaction of information with family firm with tangibility. 2.4 Interaction of information with family firm with intangibles

the treatment effect regression as instruments. Finally, in order to check whether our results are subject to selection bias, we use the Heckman two-step correction (Heckman 1979). Our results, shown in Table 4, are consistent with model VIII. Additionally, regarding model misspecifications, our findings are robust to the application of a number of different control variables. (Results are not reported).

\section{Empirical results}

Our analysis finds that the coefficients for the variables do not have the predicted signs in all regressions. The direct relationships between Information and Leverage, Tangibility and Leverage, and Intangibles and Leverage are not statistically significant. The relationship between FF and Leverage is positive and significant (model II), although it is influenced by significant moderating effects in some cases (model VIII).

This study demonstrates that, individually and within SMFF, Information $(-0.01$, model II) does not have an effect on leverage. Our study also demonstrates that, individually and within SMFF, asset structure-Tangibility (0.11, model II)—does not 
Table 4 Robustness tests

\begin{tabular}{|c|c|c|c|}
\hline & $\begin{array}{l}\text { Model VIII } \\
\text { Instrumental Variables }\end{array}$ & $\begin{array}{l}\text { Model VIII } \\
\text { Treatment Regression }\end{array}$ & $\begin{array}{l}\text { Model VIII } \\
\text { Heckman Two-step }\end{array}$ \\
\hline \multirow[t]{2}{*}{ Family firm } & 0.23 & 0.02 & 0.02 \\
\hline & $(0.16)$ & $(0.10)$ & $(0.06)$ \\
\hline \multirow[t]{2}{*}{ Information } & $0.31 *$ & 0.03 & -0.09 \\
\hline & $(0.19)$ & $(0.10)$ & $(0.13)$ \\
\hline \multirow[t]{2}{*}{ Tangibility } & -0.09 & $0.18 * *$ & -0.09 \\
\hline & $(0.35)$ & $(0.09)$ & $(0.12)$ \\
\hline \multirow[t]{2}{*}{ Reputation } & $1.05 * *$ & $-0.05^{* *}$ & $-0.06 * * *$ \\
\hline & $(0.48)$ & $(0.02)$ & $(0.02)$ \\
\hline \multirow[t]{2}{*}{ Family firm $*$ information } & $-0.48 * *$ & $-0.22 *$ & -0.22 \\
\hline & $(0.20)$ & $(0.13)$ & $(0.15)$ \\
\hline \multirow[t]{2}{*}{ Family firm * tangibility } & 0.17 & -0.11 & -0.08 \\
\hline & $(0.36)$ & $(0.09)$ & $(0.09)$ \\
\hline \multirow[t]{2}{*}{ Family firm $*$ reputation } & $-0.96 *$ & 0.015 & 0.03 \\
\hline & $(0.54)$ & $(0.03)$ & $(0.03)$ \\
\hline \multirow[t]{2}{*}{ Information $*$ tangibility } & -0.18 & -0.33 & -0.26 \\
\hline & $(0.37)$ & $(0.23)$ & $(0.27)$ \\
\hline \multirow[t]{2}{*}{ Information $*$ reputation } & $-1.02 * *$ & 0.02 & 0.03 \\
\hline & $(0.49)$ & $(0.05)$ & $(0.06)$ \\
\hline \multirow{2}{*}{$\begin{array}{l}\text { Information } * \text { reputation } * \text { family } \\
\text { firm }\end{array}$} & $1.26 * *$ & $0.23 * * *$ & $0.18^{*}$ \\
\hline & $(0.58)$ & $(0.08)$ & $(0.10)$ \\
\hline \multirow{2}{*}{$\begin{array}{l}\text { Information } * \text { tangibility } * \text { family } \\
\text { firm }\end{array}$} & $0.83 * *$ & $0.88 * * *$ & $0.98 * * *$ \\
\hline & $(0.39)$ & $(0.26)$ & $(0.32)$ \\
\hline \multirow[t]{2}{*}{ Size } & $-0.05^{*}$ & $-0.03 * * *$ & $-0.09 * * *$ \\
\hline & $(0.03)$ & $(0.01)$ & $(0.02)$ \\
\hline \multirow[t]{2}{*}{ Age } & -0.04 & $-0.04 * * *$ & -0.01 \\
\hline & $(0.04)$ & $(0.01)$ & $(0.02)$ \\
\hline \multirow[t]{2}{*}{ Profitability } & $-0.57 * * *$ & $-0.59 * * *$ & $-0.55 * * *$ \\
\hline & $(0.20)$ & $(0.06)$ & $(0.07)$ \\
\hline \multirow[t]{2}{*}{ Growth } & $0.03 * *$ & 0.01 & 0.00 \\
\hline & $(0.01)$ & $(0.01)$ & $(0.01)$ \\
\hline \multirow[t]{2}{*}{ Leverage Year-1 } & -0.05 & 0.41 & 0.54 \\
\hline & $(0.64)$ & $(0.37)$ & $(0.45)$ \\
\hline \multirow[t]{2}{*}{ Intercept } & $0.78 * *$ & $0.69 * * *$ & $1.70 * * *$ \\
\hline & $(0.40)$ & $(0.17)$ & $(0.40)$ \\
\hline Observations & 870 & 881 & 1,426 \\
\hline Hansen statistic & 0.67 & & \\
\hline
\end{tabular}

$* p<0.1$

$* * p<0.05$

$* * * p<0.01$

Robust standard errors in parentheses 
have an effect on leverage. Our results show that information transparency must be reinforced with tangible assets of high collateral value, thus supporting H1. Firms with complete Information achieve a higher debt level as Tangibility increases $(0.29$, $p<0.01$, model VI). The interaction between Information and Tangibility (Fig. 2, 2.1) give us interesting empirical: SMFF with complete Information only increase their debt level when Tangibility exceeds $50 \%$ of total assets. In the scenario of low levels of tangible assets, releasing more publicly-available financial information does not guarantee that collateral assets are enough to support a higher debt level.

Furthermore, our research also finds that there is no direct relationship between Reputation and leverage ( -0.02 , model II) in SMFF; rather this relationship is influenced by the information that the firm disseminates $(0,09, \mathrm{p}<0,05$, model VII), thus supporting H3. The interaction between Information and Reputation (Fig. 2, 2.2) provides interesting empirical evidence about this result. When the endowment of reputational intangibles is low, firms that disclose limited information $(Q=0)$ achieve higher debt levels than those which disclose complete information $(Q=1)$. It is only above a medium-high level of intangibles that complete information is preferable to incomplete information for securing more debt (Fig. 2, 2.2).

The relationship between FF and leverage is positive and significant $(0.08$, $p<0.05$, model II). Our research also finds that the potential moderating effect on this relationship of Information $(0.12$, model III), FF and Tangibility $(-0.02$, model IV) and FF and Reputation (0.01, model (V) are not statistically significant.

Our research also shows that the effect of Information and asset structure on SMFF leverage is subject to the multiplier effect of the interaction of these factors. The analysis of the triple interaction between family ownership, Information and Tangibility $(0,87, p<0,001$, model VIII) confirms H2. In this analysis and regarding the plot (Fig. 2, 2.3), we identify two possible scenarios involving SMFF and SMNFF. In the SMFF, the dual moderating effect of Information and Tangibility on debt levels is positive and significant only above a certain level of asset tangibility. But in order for the SMNFF to achieve an equivalent debt level, they need a relatively larger investment in tangible assets than SMFF do. SMNFF debt declines with the increase in the relative weight of tangible assets on the balance sheet; since they do not provide sufficient information about the nature of these assets, the capital market would be wary as to their value as collateral. The evidence reported here also indicates that, when providing the same amount of information about reputational intangibles, SMFF achieve higher debt levels than SMNFF (H4), as shown in Fig. 2, 2.4. SMFF leverage increases when a greater amount of publicly-available information is accompanied by more Reputational Intangibility $(0,22, p<0,01)$.

\section{Discussion}

The empirical evidence we find is important in relation to our first research question, indicating that the managerial models of the firm (pecking order and trade-off theories) and the behavioural models (SEW), only offer a partial understanding of the choice of capital structure in the SMFF. 
Our results in relation to the relationship between Information and leverage within SMFF, run counter to the tenets of classical finance theories (Myers 1984; Myers and Majluf 1984; Frank and Goyal 2009). Providing more publicly-disclosed information can help tackle information opacity and improve information transparency, but it is not enough to eliminate information asymmetries and thus secure more debt. This result fits with the growing evidence that financial disclosure no longer carries the same weight when it comes to resolving capital market uncertainty about a firm's solvency and business prospects (Wallman 1995; Lev and Zarowin 1999).

The results also call into question the universal collateralization value of asset tangibility in reducing agency costs and increasing leverage, as agency theory and trade-off theory predict. Investment in tangible assets is not enough to increase debt level. This result runs counter to the findings of an abundant empirical literature (e.g., Myers 1977; Myers and Majluf 1984; Williamson 1988; Frank and Goyal 2009; Sony and Bhaduri 2018; Danso et al. 2019), although other previous studies have pointed in this direction (e.g., Esperança et al. 2003). There will always be a risk that an increase in the relative weight of tangible assets on the balance sheet may be due to the immobilization of resources in tangible assets unrelated to the business (speculative investments or non-productive assets acquired for tax purposes). These could also be tangible assets that are more specific (and therefore with lower collateral value), unsuccessful, or less productive and costlier, or assets for unrelated diversification strategies in new businesses, which may not engender the trust earned in the original activities.

These results provide evidence of a gap, identified in our second research question, related to the value of the managerial model of the firm in explaining leverage in SMFF. The deterministic explanation of debt levels, based on separate analyses of the factors (publicly-available financial information and/or the endowment of tangible assets), is not confirmed by the empirical evidence in the case of SMFF. In terms of the contingency of the relationship, our second relevant contribution is to demonstrate that financial disclosure can reduce information asymmetries, or that the offer of more publicly-available information can mitigate the market risk associated with the possible existence of unproductive or non-liquid assets on the balance sheet. It can therefore increase the confidence of capital markets and the leverage in SMFF. It is shown that information transparency must be reinforced with tangible assets of high collateral value, thus supporting H1. Of course, offering more financial information or more tangible assets as collateral does help orient negotiations with providers of external financing. Both are necessary conditions to access debt capital, but they are not enough to reduce information asymmetries in all firms. The interaction between Information and Tangibility demonstrated how the collateralization of assets could be a strategy with few paths to increase the SMFF debt, because this reduced size put them in scenarios of low level of tangible assets.

Our results also show no direct relationship between Reputation and leverage in SMFF. This result would be consistent with the low collateral value of this intangible assets which financial literature postulates (Long and Malitz 1985; Gonzalez and González 2008; Frank and Goyal 2009; Campello and Giambona 2011). However, our paper identifies a category of off-balance-sheet intangibles that we refer to as reputational, which are in fact found to be relevant. Clients' and other stakeholders' 
perception of a firm's reputation and other defining features can be fed by sources that are not necessarily internal to the firm. But external stakeholders will remain slightly open to changing an image formed on the basis of indirect sources, requiring it to be validated with the direct knowledge they acquire from the company. Therefore, there is no direct relationship between a firm's endowment of reputational intangibles and leverage; rather this relationship is influenced by the information that the firm disseminates, thus supporting H3. The interaction between Information and Reputation demonstrate that it is only above a medium-high level of intangibles that complete information is preferable to incomplete information for securing more debt. This result can be explained by the fact that the uncertainty inherent in the scenario with low endowment of reputational intangibles allows stakeholders to have higher expectations of the firm's accumulated invisible assets. As this endowment of reputational intangibles grows, the financial media begins to lose confidence in the firm that limits its public information (perhaps because the scarcity of information prevents the fair assessment of business prospects and the fear of the low collateral value of intangibles prevails); conversely, this confidence is boosted when firms release complete information. This result is a valuable contribution to the literature that helps to overcome the gap in the financial theory on the collateral value of intangible assets in SMEs. Because SMFF, due to their small size, have relatively fewer tangible assets to use as collateral than large firms and a high level of these assets is necessary to guarantee their access to debt, they need to use a medium-high level of reputational intangibles for strengthening financial complete disclosure and to boost lender confidence in the firm. This conclusion sheds light on the third research question raised at the outset. The capital structure of the SMFF varies according to the endowment of specific assets it develops.

Our results contribute interesting information to the gap left by classical finance theories in the understanding of the effects of ownership structure on debt level. Although this body of research has examined the impact of factors related to the nature of shareholders on firms' capital structure, the question has not been conclusively resolved (Schmid 2013). The fact that SMFF have higher debt levels than SMNFF emphasizes the importance of non-financial criteria in determining the capital structure of firms in the former group. An important role is played by the intensity of the family desire to preserve their socioemotional wealth (Wiseman and Gomez-Mejia 1998; Gomez-Mejia et al. 2007), the desire to perpetuate the owning family's influence on the firm (Barton and Mathews 1989) and to control behavior through the presence of an owner-manager (Koropp et al. 2014). Our study suggests that, in SMFF, the general inclination seems to be towards the first preference in the trade-off between the desire of FF to maintain control-which fosters the use of debt-and risk aversion (González et al. 2013; Schmid 2013; Burgstaller and Wagner 2015) (Gallo and Vilaseca 1996; Mishra and McConaughy 1999)—which would encourage prudent attitudes toward debt. These conclusions are consistent with those of recent studies that have identified the unique behaviour of FF when it comes to making strategic decisions driven by the importance of preserving their SEW, for instance, in their internationalization strategies (Cesinger et al. 2016).

Our results also demonstrate that the confidence that the collateral value of tangible assets can reduce bankruptcy costs and mitigate moral hazard needs to be 
reinforced with the additional guarantee offered by a high level of publicly-available information, and further backed up by the long-term commitment that characterizes SMFF (Koropp, et al. 2013b). SMFF achieve higher debt levels than SMNFF (H4) and SMFF leverage increases when a greater amount of publicly-available information is accompanied by more Reputational Intangibility. This empirical evidence may mean that SMFF really are less subject to information asymmetries (Song and Wang 2013), because the financial information provided in their annual accounts reinforces the information residing in the accumulated social capital in their relationships with lenders (Chua et al. 2011). This social capital feeds on lenders' knowledge of the owning family's credit history and business reputation, of the extra care the family takes to keep its agreements in order to maintain the firm's reputation-which is closely linked to the family's reputation-and their desire for longterm survival. All these factors, which we refer to as family intangibles, reduce the risk of policies that expropriate value from lenders and therefore help to raise the debt capacity of SMFF. This result is consistent with the studies (e.g., Morck et al. 1988; Anderson and Reeb 2003) have argued that the structure of SMFF is more suited to accumulating intangible business assets, and that they would invest relatively less in tangible assets.

Information asymmetries are not the only market imperfection to play an important role in capital structure. The RBV (Barney 1991: 105; Peteraf 1993: 180-182) holds that firms' heterogeneity lies in their heterogeneous resources and capabilities; moreover, there are evidently marked differences between FF and non-FF in their asset structures (Habbershon and Williams 1999; Habbershon et al. 2003; Habbershon 2006). The existence of information asymmetries and the heterogeneity of resources are two market imperfections that should be jointly analysed in order to explain SMFF's capital structure. Our study points to the fact that in order for the family's desire to maintain transgenerational control of capital to be viable and sustainable, the SMFF must commit to developing family and business reputational intangibles that simultaneously fulfil two conditions: contributing to long-term competitive success and survival and ensuring the necessary flow of capital to the business.

In light of the evidence on these contingent effects, when dealing with the issue of capital structure there is a need to correct both the managerial vision and the behavioural vision of the FF decoupled from the importance of strategy for survival. Our last contribution is to confirm that, in the case of SMFF, the relationship between family ownership and leverage is more complex and contingent than assumed in the financial and behavioural models; this suggests the need for a shift towards comprehensive models that incorporate the strategic dimension. The SMFF's pattern of financial behaviour cannot be separated out from its strategic decisions, which are driven by economic, non-economic and strategic objectives.

The results of our research have other interesting practical implications. First, they would seem to attribute substantial value to family and business intangibles in terms of the support they provide in gaining access to debt: the value is even greater than that of the collateral offered by tangible assets, as long as information is provided that clarifies their market value. With their lower levels of information asymmetries, SMFF could continue to increase their debt capacity by combining 
large investments in tangible business assets and family and business intangibles. Conversely, the reputational intangibles that the owners of non-SMFF may have precisely because of their relative anonymity, do not confer any such advantages on these organizations. Even if this non-family ownership were made public, the market would value that reputation as less reliable backing for greater debt levels, due to the owners' difficulty in minimizing agency problems. Non-SMFF can only offer guarantees of a financial nature: the net asset value of their tangible assets. The potential for higher debt levels provided by these assets decreases with the increase in their relative weight, even in scenarios without information asymmetries. These results have some interesting policy-making implications, especially in the area of financial disclosure regulation and the new developments in non-financial information obligations. The limited value of financial disclosure in reducing information asymmetries and the growing recognition of the value of reputational intangibles as a means of improving the confidence of lenders and the competitiveness of the SMFF, should lead us to rethink the legislation on the public disclosure of corporate information.

\section{Conclusions, future research and limitations}

\subsection{Conclusions}

This study brings together three lines of research, which centred on separately examining how firms' financial structure decisions are affected by agency costs determined by information disclosure practices, tangible and intangible assets, investment decisions, and the characteristics derived from family ownership. The results point to the need for a multi-theoretical approach combining traditional financial theories, theories on the alignment of preferences and owner-manager behaviour and their application to FF, as well as strategic perspectives on resources and capabilities.

The research reveals the particular pattern of the issue of capital structure in companies that do not adhere to the managerial model of the firm because of their smaller size and family ownership. With reference to the predictions of traditional financial approaches, the results do not confirm the postulate that firms which offer lenders more information or more assets as collateral will necessarily gain easier access to the capital market due to reduced agency problems. The SMFF's pattern of financial behaviour cannot be separated out from its strategic decisions, which are driven by economic, non-economic and strategic objectives.

Our results increase the existing knowledge on the financial consequences of information asymmetries for the SMFF, calling into question the universal value of publicly-available information and asset tangibility in increasing leverage. The results confirm that the effect of the amount of publicly-available information on debt levels is positively moderated by tangible assets. Taken individually, the effects of financial disclosure and the endowment of tangible assets are not significant in explaining the debt level of SMFF. Financial disclosure can reduce uncertainty and increase the confidence of capital markets in SMFF, but this information transparency must be backed by an endowment of fixed assets in which tangible assets with high collateral value predominate. Providing more comprehensive information on 
the nature of assets clears up doubts about their quality and any specificity problems that could diminish their value as collateral.

Also, the role played by family intangibles in reducing information asymmetries can lead to an increase in bank debt based on the value of these assets as collateral, as well as an increase in non-bank leverage, by meeting the demand for comprehensive business information. The significance of the moderating effects on these relationships stemming from the SMFF provides empirical evidence of the relevance of other, non-financial theoretical perspectives and RBV in the study of capital structure. This conclusion leads us to reconsider how universally applicable the value maximization objective and owner-manager preferences are for understanding financial decisions in the SMFF. Moreover, it lends added interest to the research into the dual nature of intangibles as collateral assets and as strategic assets, as well as the way in which management should handle these assets to align their effects so that they help to reduce information asymmetries in the capital market and to create competitive asymmetries in product markets. In this regard, this paper provides novel evidence that SMFF, which due to their small size have relatively fewer tangible assets to use as collateral than large firms, can offset this disadvantage by using a medium-high level of reputational intangibles for strengthening financial complete disclosure and to boost lender confidence in the firm.

These results are particularly relevant in the context of the tourism firm given the environmental (Manniche et al. 2017) and sociocultural (Mathieson, and Wall 1982) externalities that tourism practice generates. In addition, at a strategic level, it is worth noting the sensitivity of the tourism firm to information management and to the problems of compliance and agency that are naturally present in the development of its activity. All these factors have led to attitudes of rejection towards tourism activity by the local community (Martín et al. 2018), despite the fact that tourism is a clearly poverty-reducing activity, especially in less developed countries (Dodds and Joppe 2005). This is even more relevant when analysing the Spanish tourism industry, characterized by small-sized and very often family-based companies. The current context characterized by the irruption of COVID-19 has only increased the intensity of this reality, with tourism activity having been paralyzed in practically the whole globe. The way in which the tourism company is able to maintain a high level of intangible assets will have a strong impact on its ability to extract value from the provision of financial and non-financial information, will determine the viability of its business and will be fundamental when it comes to improving relations with its stakeholders once the sanitary scenario is normalized.

\subsection{Future research}

Our study encourages the development of a line of research focused on a more indepth examination of the links between financial decisions and competitive decisions, and their implications for the financial and competitive behaviour patterns of SMFF. The joint analysis of financial and strategic decisions can be based on the study of the imperfections existing in the real markets where the firm competes and in the financial markets where it obtains its capital (Neff 2003). In both markets 
there are barriers to competition and securing financing linked to information asymmetries and the specificity of the assets used. Literature on finance, FFs and strategy should therefore take note of the need for global models to fill the existing gap.

Moreover, the matter of financial and non-financial information disclosure can be identified as an interesting line of research, which can yield recommendations and solutions for minimizing the information asymmetries in capital markets.

Finally, the literature based on the RBV opens up new lines of enquiry here, in conjunction with the existing one on information asymmetries. Similarly, it is worth examining how an SMFF's intangibles linked to its history and image can be harnessed to help the firm achieve its goal of long-term survival by improving both its debt capacity and its competitive position.

\subsection{Limitations}

This study has certain limitations. A substantial number of previous studies (e.g., Van Caneghem and Van Campenhout 2010) have empirically tested the effect of external certifications and audits of company accounts, demonstrating their positive impact on debt levels. We have not been able to test the effect of the quality of the accounting information on the financial structure, as relatively few companies in our sample are audited and the ones that are tend be fairly similar. In addition, the plots of significant interactions have in some cases yielded information that does not support the results of the statistical model. This discrepancy indicates the possible existence of a non-linear relationship — and possibly quadratic effects-between information, tangibility or intangibility and leverage, depending on whether or not there is family control of capital. A more in-depth examination of the non-linearity of these relationships can help to open the black box of FF, recognizing their heterogeneity and identifying the differential features associated with each section of the curve.

Finally, our results should be extrapolated with caution given that the sample covers a single sector (tourism), and the research is based on data referring to a time period marked by the last economic crisis, at least in its first phase. One of the reasons behind the decision to take on debt could be difficulties in self-financing due to a deterioration in profitability during a recessionary phase. However, the time period analysed ends after the economic recovery were already well underway. It could thus be supposed that the firms' decision to resort to debt arises from factors that are more structural and independent of the economic cycle.

Funding Project developed within the framework of the own research program of the Vice-Rectorate for Research of the UV, call for special actions, file UV-INV-AE-1554975. In addition, the project has funding from the State Plan for Scientific and Technical Research and Innovation 2017-2020 of the Ministry of Science and Innovation, PID2020-119642 GB-I00.

Availability of data and material Data available under request.

\section{Declarations}

Conflicts of interest The authors have no relevant financial or non-financial interests to disclose. 
Code availability Not applicable.

Ethics approval Not applicable.

Consent to participate Not applicable.

Consent for publication Not applicable.

\section{References}

Abdulsaleh AM, Worthington AC (2013) Small and medium-sized enterprises financing: a review of literature. Int J BusManag 8(14):36-54

Acock AC (2013) Discovering structural equation modeling using Stata. Stata Press Books, Los Angeles

Akerlof G (1970) The market for lemons. Qualitative uncertainty and the market mechanism. Quart J Econ 84(3):488-500

Alchian AA, Demsetz H (1972) Production, information costs, and economic organization. Am Econ Rev 62(5):777-795

Allen MF, Cote J (2005) Creditors' use of operating cash flows: an experimental study. J Manag Issues 17(2):198-211

Al-Najjar B, Hussainey K (2011) Revisiting the capital-structure puzzle: UK evidence. J Risk Finance 12(4):329-338

Amit R, Schoemaker PJ (1993) Strategic assets and organizational rent. Strateg Manag J 14(1):33-46

Ampenberger M, Schmid T, Achleitner AK, Kaserer C (2013) Capital structure decisions in family firms: empirical evidence from a bank-based economy. RMS 7(3):247-275

Anderson RC, Mansi SA, Reeb DM (2003) Founding family ownership and the agency cost of debt. J Financ Econ 68(2):263-285

Anderson RC, Reeb DM (2003) Founding-family ownership, corporate diversification, and firm leverage. J Law Econ 46(2):653-684

Andres C (2008) Large shareholders and firm performance: an empirical examination of founding-family ownership. J Corp Finan 14(4):431-445

Ang JS (1992) On the theory of finance for privately held firms. J Small Bus Manage 1(3):185-203

Ang JS, Lin J, Tyler F (1995) Evidence on the lack of separation between business and personal risks among small businesses. J Small Bus Finance 4(2-3):197-210

Audretsch DB, Elston JA (2010) Risk attitudes, wealth and sources of entrepreneurial start-up capital. J Econ Behav Organ 76(1):82-89

Barney J (1986) Strategic Factor Markets: Expectations, Luck, and Business Strategy. Manage Sci 32(10):1231-1241

Barney J (1991) Firm resources and sustained competitive advantage. J Manag 17(1):99-120

Barth ME, Clinch G (1998) Revalued financial, tangible and intangible assets: associations with shares prices and non-market based value estimates. J Account Res 36(1998):199-223

Barton SL, Matthews CH (1989) Small firm financing: Implications from a strategic management perspective. J Small Bus Manage 27(1):1-7

Becker G (1981) Altruism in the family and selfishness in the market place. Economica 48(189):1-15

Ben-Amar W, Francoeur C, Hafsi T, Labelle R (2013) What makes better boards? A closer look at diversity and ownership. Br J Manag 24(1):85-101

Berger AN, Udell GF (1995) Relationship lending and lines of credit in small firm finance. J Bus 68(3):351-381

Berger AN, Udell GF (1998) The economics of small business finance: the roles of private equity and debt markets in the financial growth cycle. J Bank Finance 22(6-8):613-673

Bertrand M, Schoar A (2006) The role of family in family firms. J Econ Perspect 20(2):73-96

Beuselinck C, Deloof M, Manigart S (2008) Private equity involvement and earnings quality. J Bus Financ Acc 36(5-6):587-615

Binks MR, Ennew CT (1994) Forum of Private Business Ltd., Knutsford (United Kingdom). 1994. Small Businesses and Their Banks 1994: Report One. Forum of Private Business. 
Bjuggren PO, Duggal R, Giang DT (2012) Ownership dispersion and capital structures in family firms: a study of closed medium-sized enterprises. J Small Bus Entrep 25(2):185-200

Blair MM, Wallman SMH (2001) Unseen wealth; report of the brookings task force on intangibles. Brookings Institution Press, Washington

Booth L, Aivazian V, Demirg-Kunt A, Maksimovic V (2001) Capital structure in developing countries. J Finance 56(1):87-130

Bopaiah C (1998) Availability of credit to family businesses. Small Bus Econ 11(1):75-86

Boubakri N, Ghouma H (2010) Control/ownership structure, creditor rights protection, and the cost of debt financing: international evidence. J Bank Finance 34(10):2481-2499

Bouzgarrou H, Navatte P (2013) Ownership structure and acquirers performance: family vs. non-family firms. Int Rev Financ Anal 27(2013):123-134

Brown S, Lo K, Lys T (1999) Use of R2 in accounting research: measuring changes in value relevance over the last four decades. J Account Econ 28(2):83-115

Bruce N, Waldman M (1990) The rotten kid theorem meets the Samaritan's dilemma. Quart J Econ 105(1):155-165

Buigues P, Jacquemin A, Marchipont JF (eds) (2000) Competitiveness and the value of intangible assets. Edward Elgar Publishing, Cheltenham

Burgstaller J, Wagner E (2015) How do family ownership and founder management affect capital structure decisions and adjustment of SMEs?: Evidence from a bank-based economy. J Risk Finance 16(1):73-101

Camisón C (2019) A theoretical framework for the analysis of the relationship between family firms and competitiveness. In: Camisón C, Cruz T (eds) Competitiveness, organizational management and governance in family firms. IGI Global, Hershey, PA

Camisón C, Monfort V (2011) La empresa turística familiar en España: importancia, perfil y competitividad. Ministerio de Industria, Energía y Turismo, Instituto de Estudios Turísticos, Madrid

Campello M, Giambona E (2011) Capital structure and the redeployability of tangible assets. Tinbergen Institute Discussion Paper

Caneghem TV, Campenhout GV (2010) Quantity and quality of information and SME financial structure. Small Bus Econ 39(2):341-358

Cavalluzzo KS, Cavalluzzo LC (1998) Market structure and discrimination: The case of small businesses. J Money, Credit Banking 771-792

Cavalluzzo KS, Cavalluzzo LC, Wolken JD (2002) Competition, small business financing, and discrimination: evidence from a new survey. J Bus 75(4):641-679

Cerqueiro G, Ongena S, Roszbach K (2016) Collateralization, bank loan rates, and monitoring. J Financ 71(3): 1295-1322

Cesinger B, Hughes M, Mensching H, Bouncken R, Fredrich V, Kraus S (2016) A socioemotional wealth perspective on how collaboration intensity, trust, and international market knowledge affect family firms' multinationality. J World Bus 51(4):586-599

Chua J, Chrisman JJ, Kellermanns F, Wu Z (2011) Family involvement and new venture debt financing. J Bus Ventur 26(4):472-488

Coco G (2000) On the use of collateral. J Econ Surv 14(2):191-214

Croci E, Doukas J, Gonenc H (2011) Family control and financing decisions. Eur Financ Manag 17(5):860-897

Cruz C, Nordqvist M (2012) Entrepreneurial orientation in family firms: a generational perspective. Small Bus Econ 38(1):33-49

Danso A, Lartey T, Fosu S, Owusu-Agyei S, Uddin M (2019) Leverage and firm investment: the role of information asymmetry and growth. Int J Acc Inf Manag, (just-accepted).

Demsetz H (1983) The structure of ownership and the theory of the firm. J Law Econ 26(2):375-390

Dillman DA (1978) Mail and telephone surveys: the total design method. Wiley, New York

Ding S, Qu B, Zhuang Z (2011) Accounting properties of Chinese family firms. J Acc Audit Financ 26(4):623-640

Dodds R, Joppe M (2005) CSR in the tourism industry?: The status of and potential for certification, codes of conduct and guidelines. IFC, Washington

Eriksen B, Mikkelsen J (1996) Competitive advantage and the concept of core competence. In: Foss N, Knudsen C (eds) Towards a competence theory of the firm. Routledge, Abingdon, pp 54-74

Ernst and Young (2019) Financial reporting developments. A comprehensive guide. Intangibles, goodwill and other. Ernst and Young, London 
Esperança JP, Gama AP, Gulamhussen MA (2003) Corporate debt policy of small firms: an empirical (re) examination. J Small Bus Enterp Dev 10(1):62-80

Fama EF, Jensen M (1983) Separation of ownership and control. J Law Econ 26(2):301-325

Fama EF, French KR (2002) Testing trade-off and pecking order predictions about dividends and debt. Rev Financ Stud 15(1):1-33

Fan JP, Wong TJ (2005) Do external auditors perform a corporate governance role in emerging markets? Evidence from East Asia. J Account Res 43(1):35-72

Farvaque E, Refati-Alexandre C, Saïdane D (2011) Corporate disclosure: a review of its (direct and indirect) benefits and costs. Ëconomie Internationale 4(128):5-31

Fombrun CJ (1996) Reputation. Harvard Business School Press, Boston

Fombrun CJ (2001) Corporate reputations as economic assets. In: Harrison JS, Hit MA, Freeman EF (eds) The Blackwell handbook of strategic management. Blackwell, New York, pp 289-312

Francis J, Schipper K (1999) Have financial statements lost their relevance? J Account Res 37(2):319-352

Frank MZ, Goyal VK (2009) Capital structure decisions: which factors are reliably important? Financ Manag 38(1):1-37

Friend I, Lang H (1988) An empirical test of the impact of managerial self-interest con corporate capital structure. J Finance 43(2):271-281

Gallo MÁ, Tàpies J, Cappuyns K (2004) Comparison of family and nonfamily business: financial logic and personal preferences. Fam Bus Rev 17(4):303-318

Gallo M, Vilaseca A (1996) Finance in family business. Fam Bus Rev 9(4):387-401

García J, García B, Penalva F (2016) Accounting conservatism and firm investment efficiency. J Account Econ 61(1):221-238

Gómez-Mejía LR, Haynes KT, Núñez-Nickel M, Jacobson KJL, Moyano-Fuentes H (2007) Socioemotional wealth and business risk in family-controlled firms: evidence from Spanish olive oil mills. Adm Sci Q 52(1):106-137

González M, Guzmán A, Pombo C, Trujillo MA (2013) Family firms and debt: risk aversion versus risk of losing control. J Bus Res 66(11):2308-2320

Gonzalez VM, González F (2008) Influence of bank concentration and institutions on capital structure: new international evidence. J Corp Finan 14(4):363-375

Govindarajan V, Rajgopal S, Srivastava A (2018) Why financial statements don't work for digital companies. Harvard Bus Rev

Grant RM (1991) The resourced-based theory of competitive advantage: implications for strategy formulation. Calif Manage Rev 33(3):114-135

Gregory BT, Rutherford MW, Oswald S, Gardiner L (2005) An empirical investigation of the growth cycle theory of small firm financing. J Small Bus Manage 43(4):382-392

Guillet BD, Mattila AS (2010) A descriptive examination of corporate governance in the hospitality industry. Int J Hosp Manag 29(4):677-684

Habbershon TG (2006) Commentary: A framework for managing the familiness and agency advantages in family firms. Entrep Theory Pract 30(6):879-886

Habbershon TG, Williams ML (1999) A resource-based framework for assessing the strategic advantages of family firms. Fam Bus Rev 12(1):1-25

Habbershon TG, Williams M, MacMillan IC (2003) A unified systems perspective of family firm performance. J Bus Ventur 18(4):451-465

Hail L (2013) Financial reporting and firm valuation: relevance lost or relevance regained? Account Bus Res 43(4):329-358

Hall R (1992) The strategic analysis of intangible resources. Strateg Manag J 13(2):135-144

Hall R (1993) A framework linking intangible resources and capabilities to sustainable competitive advantage. Strateg Manag J 14(8):607-618

Hand J, Lev B (eds) (2003) Intangible assets: values, measures, and risks. Oxford University Press, Oxford

Handler WC (1989) Methodological issues and considerations in studying family businesses. Fam Bus Rev 2(3):257-276

Heckman J (1979) Sample selection bias as a specification error. Econometrica 47(1979):153-161

Holland J (2001) Financial institutions, intangibles and corporate governance. Account Audit Account J 14(4):497-529

Jensen MC (1986) Agency costs of free cash flow, corporate finance and takeovers. Am Econ Rev 76(2):323-329 
Jensen MC, Meckling W (1976) Theory of the firm: Managerial behavior, agency costs and ownership structure. J Financ Econ 3(4):305-360

Ramalho JJS, da Silva JV (2009) A two-part fractional regression model for the financial leverage decisions of micro, small, medium and large firms. Quant Finance 9(5):621-636

Judge W (2012) Owner type as emerging area of governance research. Corp Gov: an Int Rev 20(3):231-232

Kahneman D, Tversky A (1979) Prospect theory: An analysis of decisions under risk. Econometrica 47(2):263-291

Karadeniz E, Yilmaz Kandir S, Balcilar M, Beyazit Onal Y (2009) Determinants of capital structure: evidence from Turkish lodging companies. Int J Contemp Hosp Manag 21(5):594-609

Kim J, Li L, Yi Lu, L., and Yu, Y. (2016) Financial statement comparability and expected crash risk. J Account Econ 61(2-3):294-312

Kordsachia O (2020) A risk management perspective on CSR and the marginal cost of debt: empirical evidence from Europe. RMS 15:1611-1643

Koropp C, Grichnik D, Gygax AF (2013a) Succession financing in family firms. Small Bus Econ 41(2):315-334

Koropp C, Grichnik D, Kellermanns F (2013b) Financial attitudes in family firms: the moderating role of family commitment. J Small Bus Manag 51(1):114-137

Koropp C, Kellermanns F, Grichnik D, Stanley L (2014) Financial decision making in family firms: an adaptation of the theory of planned behaviour. Fam Bus Rev 27(4):307-327

Kossovsky N (2010) Mission: intangible: managing risk and reputation to create enterprise value. Trafford Publishing, Bloomington

Larrán JM, García- Mecca E (2004) La relevancia de la información no financiera en la estrategia empresarial de divulgación voluntaria: percepciones empresa - analista sobre su utilidad. Revista Valenciana De Economía y Hacienda 12(3):127-148

Larrán M, Rees W (2003) Private disclosure in the Spanish capital market: evidence from financial analysts and investor relations directors. Span J Finance Account/revista Española De Financiación y Contabilidad 32(115):116-152

Le Breton-Miller I, Miller D, Lester H (2011) Stewardship or agency? A social embeddedness reconciliation of conduct and performance in public family businesses. Organ Sci 22(3):704-721

Lei J, Qiu J, Wan C (2018) Asset tangibility, cash holdings, and financial development. J Corp Finan 50(2018):223-242

Leland HE, Pyle DH (1977) Informational asymmetries, financial structure, and financial intermediation. J Financ 32(2):371-387

Lev B (2016) The end of accounting and the path forward for investors and managers. Wiley, New York

Lev B, Sougiannis T (1996) The capitalization, amortization, and value-relevance of R\&D. J Account Econ 21(1):107-138

Lev B, Zarowin P (1999) The boundaries of financial reporting and how to extend them. J Account Res 37(2):353-385

Li J, Wu Z, Zhang L (2019) Family involvement, external auditing, and the cost of debt: evidence fom U.S. small firms. J Small Bus Manag. https://doi.org/10.1111/jsbm.121519

Lin YC, Huang SY, Young SC (2008) An empirical study on the relationship between ownership and firm performance: Taiwan evidence. Afro Asian J Finance Account 1(1):67-80

Lippman SA, Rumelt RP (1982) Uncertain imitability: an analysis of interfirm differences in efficiency under competition. Bell J Econ 13(2):418-438

Long M, Malitz I (1985) The investment-financing nexus: some empirical evidence. Midl Corp Finance J 3(3):53-59

López-Delgado P, Diéguez-Soto J (2020) Indebtedness in family-managed firms: the moderating role of female directors on the board. RMS 14(4):727-762

López-Gracia J, Sánchez-Andújar S (2007) Financial structure of the family business: evidence from a group of small Spanish firms. Fam Bus Rev 20(4):269-287

Manniche, J., Topsø Larsen, K., Brandt Broegaard, R., and Holland, E. 2017. Destination: a circular tourism economy: a handbook for transitioning toward a circular economy within the tourism and hospitality sectors in the South Baltic Region. Nexoe: Centre for Regional and Tourism Research (CRT)

Martín JM, Guaita Martínez JM, Salinas Fernández JA (2018) An analysis of the factors behind the citizen's attitude of rejection towards tourism in a context of overtourism and economic dependence on this activity. Sustainability 10(8):28-51 
Mathieson A, Wall G (1982) Tourism, economic, physical and social impacts. Longman, Essex

Mensching H, Kraus S, Bouncken RB (2014) Socioemotional wealth in family firm research: a literature review. J Int Bus Econ 14(4):165-172

Michiels A, Molly V (2017) Financial decisions in family businesses: a review and suggestions for developing the field. Fam Bus Rev 30(4):369-399

Miller D, Le Breton-Miller I (2005) Management insights from great and struggling family businesses. Long Range Plan 38(6):517-530

Miller D, Le Breton I (2006) Family governance and firm performance: agency, stewardship and capabilities. Fam Bus Rev 19(1):73-87

Miller D, Le Breton-Miller I, Lester RH, Cannella Jr AA (2007) Are family firms really superior performers? J Corp Finance 13(5):829-858

Miller D, Le Breton-Miller I, Lester R (2011) Family and lone founder ownership and strategic behaviour: social context, identity, and institutional logics. J Manage Stud 48(1):1-25

Mishra C, McConaughy D (1999) Founding family control and capital structure: the risk of loss of control and the aversion to debt. Entrep Theory Pract 23(4):53-64

Modugu KP (2013) Capital structure decision: an overview. J Finance Bank Manag 1(1):14-27

Molly V, Laveren E, Deloof M (2010) Family business succession and its impact on financial structure and performance. Fam Bus Rev 23(2):131-147

Morck R, Shleifer A, Vishny R (1988) Management ownership and market valuation. J Financ Econ 20(1-2):293-315

Morck R, Yeung B (2003) Agency problems in large family business groups. Entrep Theory Pract 27(4):367-382

Myers SC (1977) Determinants of corporate borrowing. J Financ Econ 5(2):147-175

Myers SC (1984) The capital structure puzzle. J Financ 39(3):574-592

Myers SC (2001) Capital structure. J Econ Perspect 15(2):81-102

Myers SC, Majluf N (1984) Corporate financing and investment decisions when firms have information that investors do not have. J Financ Econ 13(2):187-221

Neff, C. 2003. Financial structure and strategic competition. In: Corporate finance, innovation, and strategic competition. Lecture notes in economics and mathematical systems, vol 522. Springer: Berlin

Nelson P (1970) Information and consumer behavior. J Polit Econ 78(2):311-329

Odit MP, Gobardhun YD (2011) The determinants of financial leverage of SME's in Mauritiuis. Int Bus Econ Res J 10(3):113-1260

Ono A, Uesegi I (2009) Role of collateral and personal guarantees in relationship lending: evidence from Japan's SME loan market. J Money Credit Bank 41(5):935-960

Ooi CA, Hooy CW, Som APM (2015) Diversity in human and social capital: empirical evidence from Asian tourist firms in corporate board composition. Tour Manage 48(2015):139-153

Origgi G (2018) Reputation: what is and why it matters. PUF, Princeton

Pearson AW, Carr JC, Shaw JC (2008) Toward a theory of familiness: a social capital perspective. Entrep Theory Pract 32(6):949-969

Peteraf MA (1993) The cornerstones of competitive advantage: a resource-based view. Strateg Manag J 14(3):179-191

Petersen MA (2009) Estimating standard errors in finance panel data sets: comparing approaches. Rev Financ Stud 22(1):435-480

Pettit RR, Singer RF (1985) Small business finance: a research agenda. Financ Manag 14(3):47-60

Pindado J, de la Requejo J, Torre C (2011) Family control and investment-cash flow sensitivity: empirical evidence from the Euro zone. J Corp Finan 17(5):1389-1409

Pindado J, Rodrigues L, de la Torre C (2006) How does financial distress affect small firms' financial structure? Small Bus Econ 26(4):377-391

Poutziouris P (2001) The views of family companies on venture capital: empirical evidence from the UK small to medium-size enterprising economy. Fam Bus Rev 14(3):277-291

Poutziouris P, Wang Y, Chan S (2002) Chinese entrepreneurship: the development of small family firms in China. J Small Bus Enterp Dev

Priem RL, Butler JE (2001) Is the resource-based "view" a useful perspective for strategic management research? Acad Manag Rev 26(1):22-40

Rajan RG, Zingales L (1995) What do we know about capital structure? Some evidence from international data. J Financ 50(5):1421-1460

Rindova V, Williamson IO, Petkova AP (2010) Reputation as an intangible asset: reflections on theory and methods in two empirical studies of business school reputations. J Manag 36(3):610-619 
Romano CA, Tanewski GA, Smyrnios KX (2001) Capital structure decision making: a model for family business. J Bus Ventur 16(3):285-310

Rovelli, P., Ferasso, M., De Massis, A., and Kraus, S. (2021). Thirty years of research in family business journals: Status quo and future directions. J Fam Bus Strategy, 100422

Schmid T (2013) Control considerations, creditor monitoring, and the capital structure of family firms. J Bank Finance 37(2):257-272

Schulze WS, Lubatkin MH, Dino RN (2003) Exploring the agency consequences of ownership dispersion among the directors of private family firms. Acad Manag J 46(2):179-194

Sciascia S, Mazzola P, Kellermanns FW (2014) Family management and profitability in private familyowned firms: introducing generational stage and the socioemotional wealth perspective. J Fam Bus Strat 5(2):131-137

Setia-Atmaja L, Tanewski GA, Skully M (2009) The role of dividends, debt and board structure in the governance of family controlled firms. J Bus Financ Acc 36(7-8):863-898

Shanker MC, Astrachan JH (1996) Myths and realities: Family businesses' contribution to the US economy. A framework for assessing family business statistics. Fam Bus Rev 9(2):107-123

Shigeru A (2017) Do family firms have worse (or better) management practices? ROETI discussion paper series 17-E-052, The Research Institute of Economy, Trade and Industry

Shleifer A, Vishny RW (1997) A survey of corporate governance. J Financ 52(2):737-783

Sibilkov V (2009) Asset liquidity and capital structure. J Financ Quant Anal 44(5):1173-1196

Song H, Wang L (2013) The impact of private and family firms' relational strength on financing performance in clusters. Asia Pac J Manag 30(3):735-748

Sony B, Bhaduri S (2018) Information asymmetry and equity issue decision of low-leverage firms: evidence from an emerging market India. Manag Financ 44(11):1330-1346

Stiglitz JE (1988) Why financial structure matters. J Econ Perspect 2(4):121-126

Stiglitz JE (2002) La información y el cambio en el paradigma de la ciencia económica. Revista Asturiana De Economía 25(2002):95-164

Stiglitz JE, Weiss A (1981) Credit rationing in markets with imperfect information. Am Econ Rev 71(3):393-410

Strebulaev IA, Yang B (2013) The mystery of zero-leverage firms. J Financ Econ 109(1):1-23

Stulz RM (1990) Managerial discretion and optimal financing policies. J Financ Econ 26(1):3-27

Thaler RH (1993) Advances in behavioral finance. The Russell Sage Foundation, New York

Tran B (2019) Corporate social responsibility. In: Advanced methodologies and technologies in business operations and management . IGI Global, NY, pp. 270-281

Tsai H, Pan S, Lee L (2011) Recent research in hospitality financial management. Int J Hosp Manag 23(7):941-971

Tse C, Rodgers T (2011) Can corporate tax shields explain the long-term borrowing behaviour of Chinese listed firms? Int Rev Financ Anal 20(2):103-112

Uhlaner L, Matser I, Berent M, Flören R (2015) Linking bonding and bridging ownership social capital in private firms: moderating effects of ownership-management overlap and family firm identity. Fam Bus Rev 28(3):1-18

Van Tendoloo B, Vanstraelen A (2008) Earning management and audit quality in Europe: evidence from the private client segment market. Eur Account Rev 17(3):447-469

Villalonga B, Amit R (2006) How do family ownership, control and management affect firm value? J Financ Econ 80(2):385-417

Voordeckers W, Le Breton-Miller I, Miller D (2014) In search of the best of both worlds: crafting a finance paper for the family business review. Fam Bus Rev 27(4):281-286

Voordeckers W, Steijvers T (2006) Business collateral and personal commitments in SME lending. J Bank Finance 30(11):3067-3086

Wallman SM (1995) The future of accounting and disclosure in an evolving world: the need for dramatic change. Account Horiz 9(3):81-91

Williamson OE (1988) Corporate finance and corporate governance. J Financ 43(3):567-591

Wiseman R, Gomez-Mejía L (1998) A behavioral agency model of managerial risk taking. Acad Manag Rev 23(1):133-153

Wu Z, Chua JH, Chrisman JJ (2007a) Effects of family ownership and management on small business equity financing. J Bus Ventur 22(8):875-895

Wu Z, Hedges PL, Zhang S (2007b) Effects of concentrated ownership and owner management on small business debt financing. J Small Bus Manag 45(4):422-437 
Yeh CM (2013) Board governance and tourist firms' performance: the case of Taiwan. J Qual Assur Hosp Tour 14(2):123-141

Yeh CM (2018) Ownership structure and firm performance of listed tourism firms. Int J Tour Res 21(3):1-15

Yeh CM, Trejos B (2015) The influence of governance on tourism firms performance. Curr Issue Tour 13(2):313-325

Yen J, Lin C, Chen Y, Huang Y (2015) Founding family firms and bank loan contracts. J Financ Serv Res 48(1):53-82

Zaheer A, Bell GG (2005) Benefiting from network position: firm capabilities, structural holes, and performance. Strateg Manag J 26(9):809-825

Publisher's Note Springer Nature remains neutral with regard to jurisdictional claims in published maps and institutional affiliations. 